<연구논문>

\title{
$\mathrm{Nd}$ YAG 레이저를 이용한 금속유물에 코팅된 아크릴수지의 제거 및 표면 특성 연구
}

\author{
이혜연 ${ }^{\mathrm{a}}$, 조남철 ${ }^{\mathrm{b} *}$
}

국립문화재연구소 복원기술연구실, ${ }^{\mathrm{b}}$ 공주대학교 문화재보존과학과

\section{Experimental Study of Nd:YAG Laser Cleaning System for Removing Acrylic Resin and Surface Characteristic}

\author{
Hye Youn Lee ${ }^{a}$, Nam Chul Cho ${ }^{b *}$ \\ ${ }^{a}$ National Research Institute of Cultural Heritage, Daejeon 305-380, Korea \\ ${ }^{b}$ Department of Cultural Heritage Conservation Science, Kongju National University, \\ Gongju 314-701, Korea
}

(Received July 26, 2012 ; revised August 29, 2012 ; accepted August 30, 2012)

\begin{abstract}
Laser cleaning have been found to be a useful cleaning tool to remove contaminants without inducing damage to the substrate and making secondary pollutant. In this study, the effect of Nd:YAG laser cleaning system, emitting at $1064 \mathrm{~nm}$ and $532 \mathrm{~nm}$, on acrylic resin applied onto copper coupons and pieces of bronze was investigated. The samples after laser cleaning tests were examined using microscopy, FT-IR, SEM-EDS. As a result, the acrylic resin could be removed from most of the samples at low laser energy density. Laser wavelength $532 \mathrm{~nm}$ was more effective than $1064 \mathrm{~nm}$ because of using lower laser energy density, which could reduce heat damage to substrates. Although the acrylic resin was easily removed, it revealed melted surfaces and removed bronze patina which must remain. The problems should be solved by future studies using different laser system or laser wavelengths.
\end{abstract}

Keywords: Laser cleaning, Acrylic resin, Nd:YAG Laser, Cleaning, Artefacts

\section{1. 서 론}

레이저클리닝이란 레이저빔을 표면에 조사하여 오염 물질을 제거하는 세정공정 기술이다. 기존의 화학적·기계적 클리닝과 다른 점은 레이저의 주요 특징인 단색성(monochromaticity)으로 인하여 모재 의 손상 없이 선택적으로 오염층만을 제거하는 것 이다. 특히 클리닝 과정 중 어떠한 오염물도 배출 하지 않은 환경 친화적인 건식세정 방식이다. 레이 저클리닝은 1972년 미국의 John Asmus에 의해 문 화재의 적용 가능성이 제시된 후 현재 유럽의 많은 나라에서 문화재 복원을 위한 레이저의 응용연구가

*Corresponding author. E-mail : nam1611@kongju.ac.kr
활발하게 진행 중에 있다 ${ }^{1}$. 초기의 레이저클리닝은 석재에 주로 적용되었으나 최근에는 스테인글라스, 가죽, 종이, 유화 등 표면 오염물 제거에 적용하여 많은 성공 사례들이 발표되고 있다. 국내에서 레이 저클리닝을 문화재에 적용한 사례로 국립문화재연 구소(1995 2005)는 경천사십층석탑의 일부 흑색 오 염물을 레이저클리닝으로 제거하였다2). 그러나 국 내에서는 석재문화재에 비해 금속문화재에 대한 레 이저클리닝 사례는 거의 없다. 이는 금속문화재의 경우 표면 오염물이 금속산화물, 부식물 등으로 금 속 모재와 오염물간의 경계가 불분명하고 표면이 불균일하여 레이저클리닝을 적용하기 어렵기 때문 이다. 그러나 국외에서는 철, 청동, 금, 은과 같은 금속문화재표면의 부식물, 왁스, 잉크 등 표면 이물 
질 제거에 레이저클리닝의 적용 연구가 진행되고 있다 ${ }^{3-5)}$.

고분자수지는 금속유물의 보존처리 과정에서 표 면을 보호해주고 취약한 구조를 강화 및 지지하는 역할을 수행하고 있다. 고분자수지 중 아크릴수지 는 금속문화재 보존처리에 광범위하게 사용되고 있 다. 그러나 아크릴수지는 시간이 경과함에 따라 자 외선, 습도, 온도 등의 환경요인과 광산화 반응이 일어나 그 결과 폴리머 결합이 파괴되고 새로운 가 교결합이 형성되어 용제로 제거되지 않는 구조를 형성한다. 또한 이러한 구조적 변화는 표면 변색과 수지 기능의 손실을 가져온다 ${ }^{6}$. 따라서 금속유물의 재처리를 위해서는 노화된 수지를 제거하여야 한다. 현재 노후된 아크릴수지는 화학적 용제로 제거하고 있으나 이는 작업자와 주변 환경에 유해하며 유물 에 손상을 줄 수 있으므로 현재 아크릴수지를 안전 하고 효과적으로 제거할 수 건식세정방식이 요구되 고 있다. 그러므로 본 연구에서는 다양한 산업현장 의 클리닝 공정에서 사용되고 있는 Nd:YAG 레이 저기기를 이용하여 아크릴수지 제거에 적용하고 실 제 금속문화재 보존처리의 적용 가능성을 알아보고 자 한다.

\section{2. 실험방법}

\section{1 시편 제작}

레이저클리닝을 실험할 아크릴수지는 현재 금속 유물보존처리에서 많이 사용되고 있는 Paraloid NAD10, Paraloid B72으로 선정하였다. Paraloid NAD10은 Rohm \& Hass Co.에서 개발한 아크릴수 지로 나프타(naphtha)에 용해된 비수용성 에멀전이 다. 용액상태에서 유백색을 띠고 점착력이 있으나 건조 후 투명하며 광택이 있다. 또한 보호피막을 두 껍게 형성하기 때문에 철제유물의 강화처리제로 많 이 사용되고 있다. Paraloid B72는 Rohm \& Hass Co.에서 개발한 상품으로 poly methyl acrylate와 poly ethyl methacrylate(MA/EMA)의 공중합체물질 이다. 톨루엔, 아세톤 등의 다양한 용제에 용해가 가능하고 가역성이 뛰어나 석재, 금속, 목재 유물의 강화 및 코팅제로 사용되고 있다 ${ }^{7,8)}$.

선정된 아크릴수지는 각각의 용제, 즉 Paraloid NAD10은 나프타에, Paraloid B72는 아세톤에 $10 \cdot 20 \cdot 30 \mathrm{wt} \%$ 의 농도로 용해하여 준비하였다. 아 크릴수지를 코팅할 대상은 동 $(\mathrm{Cu})$ 판과 청동유물편 이다. 동판의 크기는 세로 $60 \mathrm{~mm}$ 가로 $\cdot 35 \mathrm{~mm}$ - 두 께 $2 \mathrm{~mm}$ 이며 실험 전 표면에 흡착된 불순물을 제
거하고 균일한 코팅을 위하여 연마지 \#100부터 \#800 까지 연마하였다. 연마 후 표면의 이물질을 제거하 기 위하여 에탄올에 침적시켜 5 분 동안 초음파 세 척기로 세척하였으며 세척이 완료된 시편을 에어블라우워(blower)를 이용하여 건조하였다. 아크릴수 지 코팅 방법은 건조된 동판을 용액에 침적시켰다 가 일정한 속도로 꺼내는 Dip-coating 방식으로 코 팅하였으며 24시간 동안 자연 건조시켜 코팅을 완 료하였다.

아크릴수지의 노화 전·후 레이저클리닝 효과를 알아보기 위하여 코팅된 동판을 60 일간 자외선에 노출시켜 노화시켰다. 실험에 사용된 자외선 조사 기는 Ultraviolet Fluorescence Analysis Cabinet (Model CL-150, Spectroline Co.)이며 파장 $254 \mathrm{~nm}$ 와 $365 \mathrm{~nm}$ 을 출력한다. 시편사진은 그림 1 과 같으 며 실험 목록은 표 1 로 정리하였다.

\section{2 레이저클리닝 기기}

본 실험에서 사용한 $\mathrm{Q}-\mathrm{Switch}$ 가 부착된 $\mathrm{Nd}: \mathrm{YAG}$ 레이저기기(IMT社 iMT800MV)는 두 가지 레이저 파장, 즉 $1064 \mathrm{~nm}$ 와 $532 \mathrm{~nm}$ 모드를 가지며, $1064 \mathrm{~nm}$ 는 $160 \sim 800 \mathrm{~mJ}, 532 \mathrm{~nm}$ 는 $50 \sim 350 \mathrm{~mJ}$ 의 레이저에너 지를 출력한다. 또한 단일 레이저 펄스의 지속 시 간을 의미하는 펄스 길이는 10 nanosecond이다.

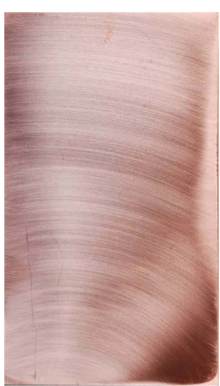

(a)

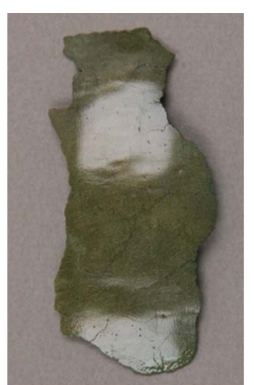

(b)
Fig. 1. Samples of laser cleaning for removing acrylic resin: (a) a plain copper coupon, (b) a piece of bronze artefact.

Table 1. Details of acrylic resin and substrates

\begin{tabular}{|c|c|c|c|c|}
\hline \multirow{2}{*}{ Acrylic Resin } & \multirow{2}{*}{ Solvent } & \multicolumn{3}{|c|}{ Concentration (wt\%) } \\
\cline { 3 - 5 } & & 10 & 20 & 30 \\
\hline Paraloid NAD10 & Naphtha & N10 & N20 & N30 \\
\hline Paraloid B72 & Acetone & B10 & B20 & B30 \\
\hline
\end{tabular}

\begin{tabular}{|c|c|c|}
\hline Substrates & \multicolumn{2}{|c|}{ Ageing } \\
\hline Copper coupon & no ageing & ageing \\
\hline Brozne artefact & \multicolumn{2}{|c|}{ no ageing } \\
\hline
\end{tabular}


Table 2. Laser irradiation condition for this study

\begin{tabular}{|c|c|c|c|c|c|c|c|c|c|c|c|c|c|}
\hline Laser Wavelength $(\mathrm{nm})$ & \multicolumn{5}{|c|}{1064} & \multicolumn{5}{|c|}{532} \\
\hline Laser Energy $(\mathrm{mJ})$ & 200 & 300 & 400 & 500 & 600 & 700 & 800 & 100 & 150 & 200 & 250 & 300 & 350 \\
\hline Laser Energy Density $\left(\mathrm{J} / \mathrm{cm}^{2}\right)$ & 0.67 & 1.00 & 1.33 & 1.67 & 2.00 & 2.33 & 2.67 & 0.33 & 0.50 & 0.67 & 0.83 & 1.00 & 1.17 \\
\hline
\end{tabular}

\section{3 실험 및 분석방법}

아크릴수지를 코팅한 동판과 청동유물편에 레이 저 파장 $1064 \mathrm{~nm}$ 와 $532 \mathrm{~nm}$ 별로 레이저에너지를 증가시키며 1회(1 pulse) 조사하였다. 레이저에너지 밀도는 레이저빔이 시편에 조사되는 면적과 레이저 에너지로 조절하였다. 레이저에너지밀도(energy density)는 레이저 공정시 널리 사용되는 단위 중 하나로 이는 단위 면적당 입사되는 펄스 에너지이 며 단위는 $\mathrm{J} / \mathrm{cm}^{2}$ 이고 레이저 플루언스(Fluence)라고 도 한다. 본 논문에서는 레이저에너지 $(\mathrm{mJ})$ 와 레이 저에너지밀도 $\left(\mathrm{J} / \mathrm{cm}^{2}\right)$ 를 함께 사용하였다. 본 실험에 서 사용된 레이저파장 $1064 \mathrm{~nm}$ 는 $0.67 \sim 2.67 \mathrm{~J} / \mathrm{cm}^{2}$, $532 \mathrm{~nm}$ 는 $0.33 \sim 1.17 \mathrm{~J} / \mathrm{cm}^{2}$ 의 레이저에너지밀도가 적 용되었으며 이 때 레이저빔이 조사되는 면적은 $0.3 \mathrm{~cm}^{2}$ 으로 타원형이다. 실험의 레이저에너지밀도 간격은 표 2에 나타내었다.

레이저 조사 전·후 시료의 표면을 비교하기 위해 실체현미경(MZ75, LEICA)과 금속현미경(DM2500M, LEICA)으로 확대하여 관찰하였으며 디지털 카메 라(D200, Nikon)로 촬영하였다. 레이저 조사 전·후 아크릴수지의 성분변화 및 잔류 여부를 FT-IR (Spectrum 100, Perkin Elmer) 분석으로 500 $4000 \mathrm{~cm}^{-1}$ 파장영역을 측정하고 흡수 피크의 변화 양상을 관찰하였다. 또한 레이저클리닝 후 표면의 미세형태 및 수지 잔류 여부를 SEM-EDS(JSM$7401 \mathrm{~F}, \mathrm{JEOL} \cdot \mathrm{QUANTAX800,}$ Burker) 분석으로 알아보았다.

\section{3. 결과 및 고찰}

\section{1 동판에 코팅된 아크릴수지 제거}

3.1 .1 동판에 코팅된 아크릴수지의 두께 측정 아크릴수지 코팅 후 농도별 두께를 알아보기 위 하여 $\mathrm{SEM}$ 으로 단면 3곳을 측정, 평균을 계산하였 다. 측정결과 Paraloid NAD10의 경우 $10 \mathrm{wt} \%$ 에서 $3.68 \mu \mathrm{m}, 20 \mathrm{wt} \%$ 에서 $16.37 \mu \mathrm{m}, 30 \mathrm{wt} \%$ 에서 $17.34 \mu \mathrm{m}$ 로 측정되어 $20 \mathrm{wt} \%$ 와 $30 \mathrm{wt} \%$ 는 두께의 차이가 거 의 없으나 $10 \mathrm{wt} \%$ 와는 큰 두께 차이를 보여주었다. Paraloid B72의 경우는 $10 \mathrm{wt} \%$ 에서 $1.43 \mu \mathrm{m}, 20 \mathrm{wt} \%$ 에서 $7.78 \mu \mathrm{m}, 30 \mathrm{wt} \%$ 에서 $6.84 \mu \mathrm{m}$ 로 측정되어 Paraloid NAD10과 유사하게 $10 \mathrm{wt} \%$ 와 $20 \cdot 30 \mathrm{wt} \%$ 는 두께 차이가 크게 코팅되었으나 $20 \mathrm{wt} \%$ 와
$30 \mathrm{wt} \%$ 의 두께 차이는 거의 없음을 확인할 수 있 었다.

아크릴수지 간의 차이를 비교하면 Paraloid NAD10 의 수지 두께가 Paraloid B72의 수지 두께보다 2 3배 두껍게 측정되었다. 이는 수지의 용제 증발율 (evaporation rate)과 관계가 있다. 고분자 수지의 코 팅 두께는 대체로 용액의 농도, 점도, pulling-up speed 등에 의해 결정된다. 본 실험에서 pulling-up speed는 일정하게 유지하였으므로 용액의 농도, 점 도, 증발율(evaporation rate)과 관계가 있다. 일반적 으로 박막두께는 용액의 농도가 증가할수록 두께와 점도가 증가한다 ${ }^{9)}$. 본 실험의 용제 증발율은 $25^{\circ} \mathrm{C}$ 에서 ether를 1로 보았을 때 나프타는 43이며 아세 톤은 2.1 이다 ${ }^{10)}$. 박막의 두께는 용제의 증발속도가 빠르고 점도가 클수록 두껍게 형성한다. 그러므로 본 실험에서는 점도를 측정하지 않았으나 아세톤보 다 증발율이 약 21 배나 빠른 나프타를 사용한 Paraloid NAD10의 박막 두께가 더 두껍게 코팅됨 을 확인할 수 있었다. 두께 측정결과는 표 3 에 정 리하였으며 그림 2 는 두께 측정한 $\mathrm{SEM}$ 사진이다.

\subsection{2 레이저 조사 전·후 실체현미경 관찰}

동판에 코팅된 Paraloid NAD10의 경우 레이저파 장 $1064 \mathrm{~nm}$ 를 사용하였을 때 노화전 $10 \mathrm{wt} \%$ 에서는 $2.33 \mathrm{~J} / \mathrm{cm}^{2}$ 부터 일부분이 제거되었으며 $2.67 \mathrm{~J} / \mathrm{cm}^{2}$ 이 상에서 레이저빔과 동일한 면적의 수지가 제거되었 다. 동일 면적이 제거된 경우 수지가 완전히 제거 되었다고 보았다. $20 \mathrm{wt} \%$ 와 $30 \mathrm{wt} \%$ 는 $2.00 \mathrm{~J} / \mathrm{cm}^{2}$ 에 서 일부분이 제거되었으며 $2.67 \mathrm{~J} / \mathrm{cm}^{2}$ 에서 완전히

Table 3. Thickness of acrylic resin film (ageing) in terms of resin concentration (wt\%)

\begin{tabular}{|c|c|c|c|c|}
\hline \multirow{2}{*}{$\begin{array}{c}\text { Acrylic } \\
\text { Resin }\end{array}$} & \multirow{2}{*}{$\begin{array}{c}\text { Thickness } \\
(\mu \mathrm{m})\end{array}$} & \multicolumn{3}{|c|}{ Concentration (wt\%) } \\
\cline { 3 - 5 } & 1 & 3.94 & 18.56 & 18.28 \\
\hline \multirow{3}{*}{$\begin{array}{c}\text { Paraloid } \\
\text { NAD10 } \\
\text { (in Naphtha) }\end{array}$} & 2 & 3.84 & 15.75 & 17.44 \\
\cline { 2 - 5 } & 3 & 3.28 & 14.81 & 16.31 \\
\cline { 2 - 5 } & average & 3.68 & 16.37 & 17.34 \\
\hline & 1 & 1.78 & 7.50 & 7.55 \\
\cline { 2 - 5 } & 2 & 1.36 & 7.59 & 6.47 \\
\cline { 2 - 5 } $\begin{array}{c}\text { Paraloid B72 } \\
\text { (in Acetone) }\end{array}$ & 3 & 1.17 & 8.25 & 6.52 \\
\cline { 2 - 5 } & average & 1.43 & 7.78 & 6.84 \\
\hline
\end{tabular}




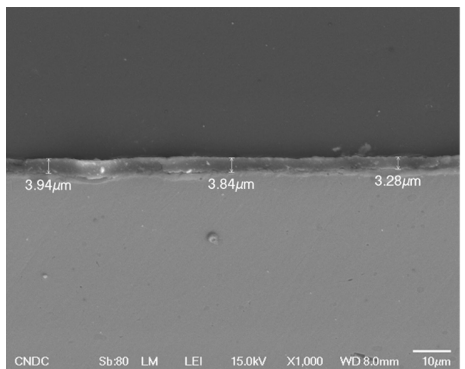

(a) N10

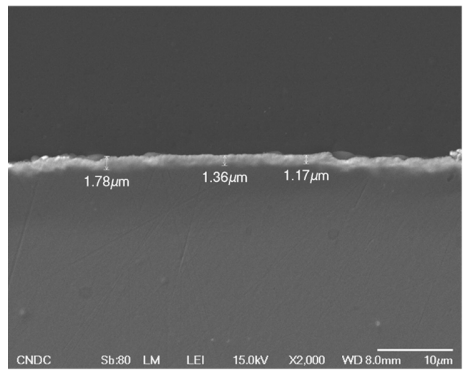

(d) B10

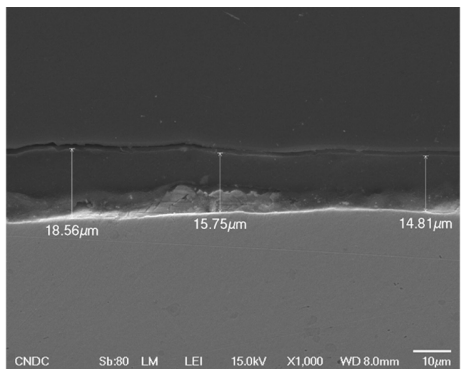

(b) N20

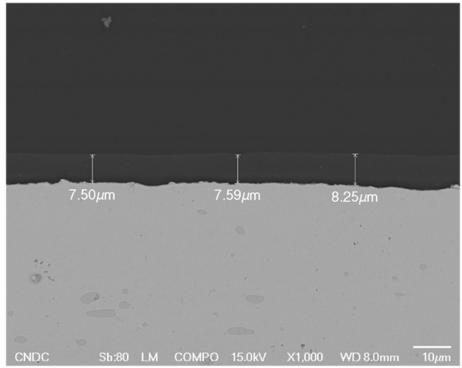

(e) B20

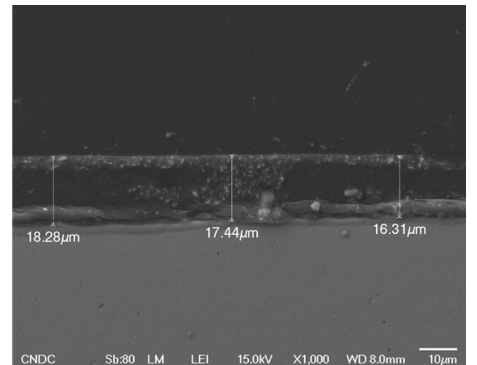

(c) $\mathrm{N30}$

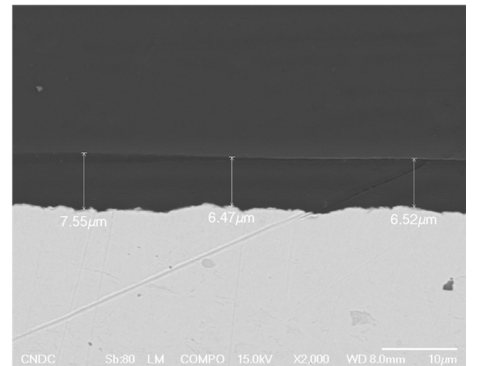

(f) $\mathrm{B} 30$

Fig. 2. SEM image for thickness of acrylic resin film (ageing) on the copper in terms of resin concentration (wt\%).

제거되었다. 노화 후 $10 \mathrm{wt} \%$ 와 $20 \mathrm{wt} \%$ 는 $1.00 \mathrm{~J} / \mathrm{cm}^{2}$ 에서 일부분이 제거되었으며 $1.67 \mathrm{~J} / \mathrm{cm}^{2}$ 에서 완전히 제거되었으며 $30 \mathrm{wt} \%$ 의 경우는 $2.00 \mathrm{~J} / \mathrm{cm}^{2}$ 에서 완 전히 제거되었다. $532 \mathrm{~nm}$ 의 레이저파장을 사용한 경우는 노화 전 $10 \mathrm{wt} \%$ 에서는 $0.50 \mathrm{~J} / \mathrm{cm}^{2}$ 에서 일부 분이 제거되었으며 $0.83 \mathrm{~J} / \mathrm{cm}^{2}$ 에서 완전히 제거되었 다. $20 \mathrm{wt} \%$ 와 $30 \mathrm{wt} \%$ 에서는 $0.67 \mathrm{~J} / \mathrm{cm}^{2}$ 에서 일부 제 거되었으며 $1.00 \mathrm{~J} / \mathrm{cm}^{2}$ 에서 완전히 제거되었다. 노 화 후에는 $10 \mathrm{wt} \%$ 와 $20 \mathrm{wt} \%$ 에서 $0.50 \mathrm{~J} / \mathrm{cm}^{2}$ 에서 일 부 제거되었으며 $0.67 \mathrm{~J} / \mathrm{cm}^{2}$ 에서 완전히 제거되었으 며 $30 \mathrm{wt} \%$ 에서는 $0.50 \mathrm{~J} / \mathrm{cm}^{2}$ 에서 제거되기 시작하 였으며 $0.83 \mathrm{~J} / \mathrm{cm}^{2}$ 에서 완전히 제거되었다.

Paraloid B-72 수지는 레이저파장 $1064 \mathrm{~nm}$ 를 사 용한 경우 노화 전 $10 \mathrm{wt} \%$ 와 $20 \mathrm{wt} \%$ 의 농도에서는 약 $1.00 \mathrm{~J} / \mathrm{cm}^{2}$ 이상부터 반응이 시작되었으며 $2.33 \mathrm{~J} /$ $\mathrm{cm}^{2}$ 에서 완전히 제거되었다. 그러나 $30 \mathrm{wt} \%$ 의 경우 본 실험에서 사용된 가장 높은 레이저에너지밀도인 $2.67 \mathrm{~J} / \mathrm{cm}^{2}$ 에서도 거의 반응이 일어나지 않았다. 노 화시킨 경우는 $10,20,30 \mathrm{wt} \%$ 에서 약 $1.00 \mathrm{~J} / \mathrm{cm}^{2}$ 에 서 제거되기 시작하였으며 $10 \mathrm{wt} \%$ 와 $20 \mathrm{wt} \%$ 는 $1.67 \mathrm{~J} / \mathrm{cm}^{2}$ 에서, $30 \mathrm{wt} \%$ 는 $2.00 \mathrm{~J} / \mathrm{cm}^{2}$ 에서 완전히 제 거되었다. 레이저파장 $532 \mathrm{~nm}$ 를 사용한 경우 노화 전 $10,20,30 \mathrm{wt} \%$ 에서 $0.50 \mathrm{~J} / \mathrm{cm}^{2}$ 에서 제거되기 시 작되었으며 $10 \mathrm{wt} \%$ 는 $0.83 \mathrm{~J} / \mathrm{cm}^{2}, 20 \mathrm{wt} \%$ 와 $30 \mathrm{wt} \%$ 는 $1.00 \mathrm{~J} / \mathrm{cm}^{2}$ 에서 완전히 제거되었다. 노화된 후에 는 $10 \mathrm{wt} \%, 20 \mathrm{wt} \%, 30 \mathrm{wt} \%$ 는 $0.50 \mathrm{~J} / \mathrm{cm}^{2}$ 에서 일부 제거되기 시작하였으며 $10 \mathrm{wt} \%$ 는 $0.83 \mathrm{~J} / \mathrm{cm}^{2}, 20 \mathrm{wt} \%$ 와 $30 \mathrm{wt} \%$ 는 $1.00 \mathrm{~J} / \mathrm{cm}^{2}$ 에서 완전히 제거되었다.
아크릴수지에 대한 레이저클리닝 결과를 실체현 미경으로 관찰한 결과 $1064 \mathrm{~nm}$ 는 노화 전에 2.33 $2.67 \mathrm{~J} / \mathrm{cm}^{2}$, 노화 후에는 $1.67 \sim 2.00 \mathrm{~J} / \mathrm{cm}^{2}$ 의 레이저에 너지밀도로 제거되었으며 $532 \mathrm{~nm}$ 는 노화 전에 0.83 $1.00 \mathrm{~J} / \mathrm{cm}^{2}$, 노화 후에는 $0.67 \sim 1.00 \mathrm{~J} / \mathrm{cm}^{2}$ 로 제거되었 다. 따라서 레이저 조사에 대한 반응성은 노화 전 보다 노화 후가 더 높았으며 농도가 높아질수록 제 거에 필요한 레이저에너지는 약간 증가하였다. 또 한 $1064 \mathrm{~nm}$ 보다 $532 \mathrm{~nm}$ 를 사용할 때 더 낮은 레 이저에너지밀도로 제거가 가능하였다. 이는 자외선 에 노출된 수지의 폴리머 간 결합력이 약화되어 레 이저빔에 의해 쉽게 파괴되기 때문이며 짧은 파장 을 사용할수록 레이저의 에너지가 증가하기 때문에 $1064 \mathrm{~nm}$ 보다는 $532 \mathrm{~nm}$ 가 더 낮은 레이저에너지밀 도로 제거가 가능한 것으로 판단된다.

아크릴수지의 두께에 따른 레이저 조사 결과 두 아크릴수지 모두 $10 \mathrm{wt} \%$ 에 비해 $20 \cdot 30 \mathrm{wt} \%$ 의 두 께가 약 46 배 이상이지만 제거에 필요한 레이저에 너지밀도의 차이는 크지 않았다. 또한 Paraloid B72 의 경우 $20 \mathrm{wt} \%$ 와 $30 \mathrm{wt} \%$ 의 두께차이는 거의 없었 으나 $30 \mathrm{wt} \%$ 노화전 수지의 경우 레이저에 거의 반 응하지 않았다. 따라서 아크릴수지를 제거하는데 필 요한 레이저에너지밀도는 두께보다는 농도나 밀도, 접착력 등의 변수가 있음을 알 수 있었다.

표 4의 값은 실체현미경 관찰 결과 조사된 레이 저빔 면적과 동일하게 제거된 경우의 레이저에너지 밀도이며 그림 3 은 제거된 표면의 실체현미경 사진 이다. 
Table 4. Ablation thresholds of copper coupon coated with acrylic resin (Unit : $\mathrm{J} / \mathrm{cm}^{2}$, - : no reaction)

\begin{tabular}{|c|c|c|c|c|c|c|c|}
\hline \multirow{2}{*}{$\begin{array}{c}\text { Laser Wavelength } \\
(\mathrm{nm})\end{array}$} & \multirow{2}{*}{ Ageing } & \multicolumn{3}{|c|}{ Palaroid NAD10 } & \multicolumn{3}{c|}{ Paraloid B72 } \\
\cline { 3 - 9 } & & $10 \mathrm{wt} \%$ & $20 \mathrm{wt} \%$ & $30 \mathrm{wt} \%$ & $10 \mathrm{wt} \%$ & $20 \mathrm{wt} \%$ & $30 \mathrm{wt} \%$ \\
\hline \multirow{3}{*}{1064} & non-ageing & 2.67 & 2.67 & 2.67 & 2.33 & 2.33 & - \\
\cline { 2 - 9 } & ageing & 1.67 & 1.67 & 2.00 & 1.67 & 1.67 & 2.00 \\
\hline \multirow{2}{*}{532} & non-ageing & 0.83 & 1.00 & 1.00 & 0.83 & 1.00 & 1.00 \\
\cline { 2 - 9 } & ageing & 0.67 & 0.67 & 0.83 & 0.83 & 1.00 & 1.00 \\
\hline
\end{tabular}

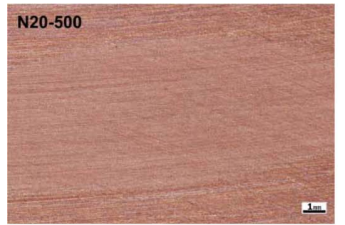

(a) $1064 \mathrm{~nm}, 1.67 \mathrm{~J} / \mathrm{cm}^{2}$

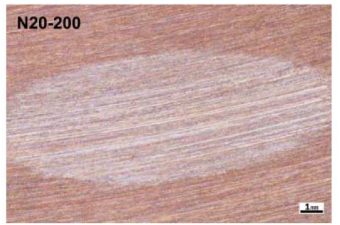

(b) $532 \mathrm{~nm}, 0.67 \mathrm{~J} / \mathrm{cm}^{2}$

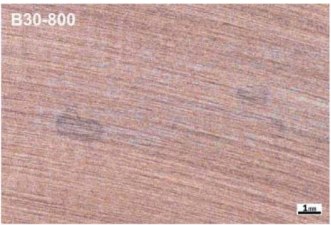

(c) $1064 \mathrm{~nm}, 2.67 \mathrm{~J} / \mathrm{cm}^{2}$

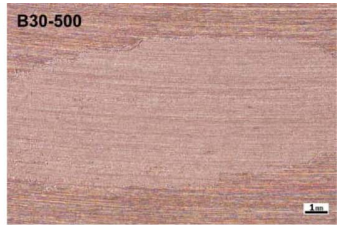

(d) $1064 \mathrm{~nm}, 1.67 \mathrm{~J} / \mathrm{cm}^{2}$

Fig. 3. Optical microscopy of copper coupon after laser irradiation; (a),(b) Paraloid NAD10 after ageing (removed), (c) Paraloid B72 before ageing (not removed), (d) Paraloid B72 after ageing (removed).

\subsection{3 레이저 조사 전·후 표면의 FT-IR 분석}

노화된 아크릴수지의 레이저 조사 후 표면의 수지 잔류 여부를 FT-IR 분석으로 알아보았다. Paraloid NAD10와 Paraloid B72의 FT-IR 분석결과 3600 $3200 \mathrm{~cm}^{-1}$ 넓은 영역 파장범위에서 나타나는 -OH 와 $3000 ~ 2850 \mathrm{~cm}^{-1}$ 에서 나타나는 날카로운 피크인 methylene group의 $\mathrm{C}-\mathrm{H}$ 가 검출되었으며 아크릴계 수지의 특징인 $\mathrm{C}=\mathrm{O}$ 이 $1740 ~ 1720 \mathrm{~cm}^{-1}$ 밴드에서 강 한 피크와 $1475 ~ 1450 \mathrm{~cm}^{-1}$ 와 $1000 \sim 950 \mathrm{~cm}^{-1}$ 밴드에 서 약한 피크가 검출되었닿.

레이저파장 $1064 \mathrm{~nm}$ 으로 Paraloid NAD10와 Paraloid $\mathrm{B} 72$ 를 조사한 경우 실체현미경 관찰시 약 1.67 2.00 $\mathrm{J} / \mathrm{cm}^{2}$ 에서 제거되었으나 FT-IR 분석결과 레이저에 너지밀도가 높아질수록 흡수피크의 강도는 약해지 지만 아크릴계 수지의 흡수피크가 검출되었다. 따
라서 $1064 \mathrm{~nm}$ 를 사용한 경우 아크릴수지가 완전히 제거되지 않았음을 확인할 수 있었다(그림 $4 \mathrm{a}$ ).

레이저파장 $532 \mathrm{~nm}$ 를 사용한 경우 Paraloid NAD10 수지 제거 후 실체현미경으로 관찰시 $10 \mathrm{wt} \%$ 와 $20 \mathrm{wt} \%$ 에서 $0.67 \mathrm{~J} / \mathrm{cm}^{2}, 30 \mathrm{wt} \%$ 에서는 $0.83 \mathrm{~J} / \mathrm{cm}^{2}$ 에 서 제거되었다. FT-IR 분석 결과 $10 \mathrm{wt} \%$ (그림 $4 \mathrm{~b}$ ) 와 $20 \mathrm{wt} \%$ 에서는 실체현미경 관찰보다 낮은 레이 저에너지밀도인 약 $0.50 \mathrm{~J} / \mathrm{cm}^{2}$ 부터 아크릴계 수지의 흡수 피크가 검출되지 않았으며 $30 \mathrm{wt} \%$ 에서 약 $0.83 \mathrm{~J} / \mathrm{cm}^{2}$ 부터 흡수피크가 검출되지 않아 실체현미 경과 유사한 결과가 확인되었다. 그러나 Paraloid $\mathrm{B} 72$ 를 $532 \mathrm{~nm}$ 로 조사한 경우는 $1064 \mathrm{~nm}$ 의 결과와 유사하게 실체현미경 관찰 시 $0.83 \sim 1.00 \mathrm{~J} / \mathrm{cm}^{2}$ 에서 제거되었으나 FT-IR 분석결과 흡수피크의 강도는 약해지지만 동일한 흡수밴드에서 피크가 검출되어

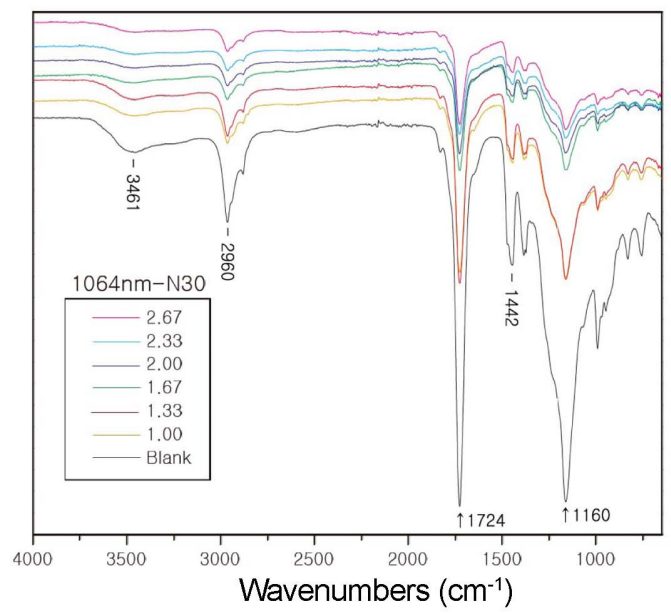

(a) $1064 \mathrm{~nm}$ 30wt\% Paraloid NAD10

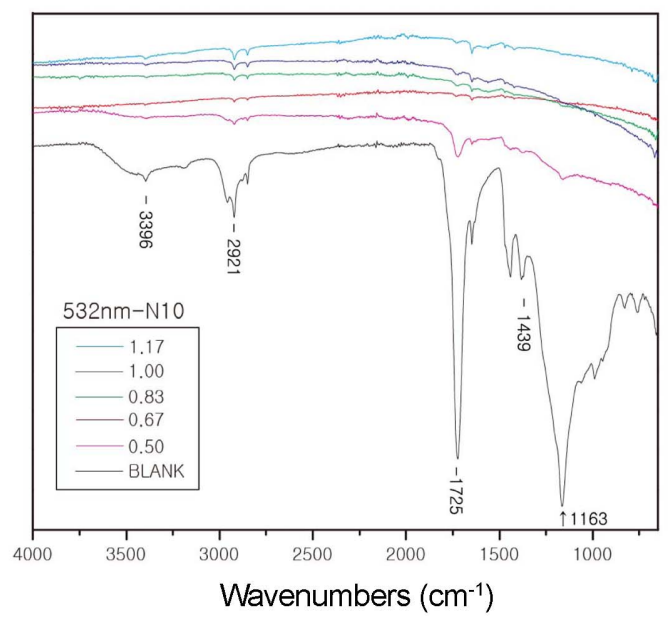

(b) $532 \mathrm{~nm} \mathrm{10wt \%} \mathrm{Paraloid} \mathrm{NAD10}$

Fig. 4. FT-IR of copper coupon coated with acrylic resin after laser irradiation. 
아크릴수지가 완전히 제거되지 않았음을 확인하였 다. 따라서 FT-IR 분석결과 Paraloid NAD10 제거 하는데 레이저파장 $532 \mathrm{~nm}$ 를 사용하는 것이 가장 효과적임을 알 수 있었다.

\subsection{4 레이저 조사 전·후 표면의 SEM-EDS 분석} 레이저 조사 전·후 동판 표면의 미세형태 변화 를 SEM-EDS로 분석하였다. 먼저 소지금속에 대한 레이저빔의 영향을 알아보기 위하여 수지를 코팅하 지 않은 동판에 레이저빔을 조사한 후 표면 변화를 알아보았다. 레이저파장 $1064 \mathrm{~nm}$ 의 경우 약 $2.00 \mathrm{~J} /$ $\mathrm{cm}^{2}$ 부터 표면에 미세하게 용융현상이 발생하였으며 $532 \mathrm{~nm}$ 의 경우에는 약 $1.00 \mathrm{~J} / \mathrm{cm}^{2}$ 부터 용융현상이 발생하기 시작하였다. 따라서 $1064 \mathrm{~nm}$ 는 $2.00 \mathrm{~J} / \mathrm{cm}^{2}$ 미만, $532 \mathrm{~nm}$ 는 $1.00 \mathrm{~J} / \mathrm{cm}^{2}$ 미만의 레이저에너지밀 도를 사용하는 것이 소지금속에 안전한 레이저에너 지 조건임을 확인하였다(그림 $5 \mathrm{a}, \mathrm{b}$ ).

실체현미경으로 수지가 제거된 것으로 관찰되지 만 FT-IR 분석결과 수지의 흡수피크가 검출된 표면 을 SEM-EDS로 분석하였다. 그림 5의 (c)는 레이저 조건 $1064 \mathrm{~nm} 2.67 \mathrm{~J} / \mathrm{cm}^{2}$ 로 $30 \mathrm{wt} \%$ Paraloid NAD 10 을 조사한 후 SEM-EDS 분석한 결과로 표면에 잔류물이 확인되었다. 잔류한 물질 Fig. 5(c)-1)을 $\mathrm{EDS}$ 로 분석한 결과 $78.30 \mathrm{wt} \% \mathrm{C}$ 가 검출되어 잔류 한 수지임을 알 수 있었으며 (c)-2)는 $86.74 \mathrm{wt} \% \mathrm{Cu}$ 와 소량의 $\mathrm{O}$ 와 $\mathrm{C}$ 가 검출되어 동판 소지임을 확인 하였다(표 5). 따라서 SEM-EDS 분석결과 일부 소 량의 수지가 잔류하고 있는 경우 실체현미경에서 제거된 것으로 관찰되나 FT-IR 분석에서 수지가 검 출되고 있음을 확인하였다.

\section{2 청동유물에 코팅된 아크릴수지 제거}

\subsection{1 레이저 조사 전·후 현미경 관찰}

아크릴수지가 코팅된 청동유물편에 레이저를 조 사한 후 표면의 변화를 실체현미경과 금속현미경으 로 관찰하였다. Paraloid NAD10의 경우 $1064 \mathrm{~nm}$ 의
Table 5. EDS results of copper coupon coated with acrylic resin after laser irradiation

\begin{tabular}{|l|c|c|c|c|}
\hline \multicolumn{2}{|c|}{ SEM-EDS } & \multicolumn{3}{c|}{ Chemical composition (wt\%) } \\
\cline { 3 - 5 } & $\mathrm{Cu}$ & $\mathrm{O}$ & $\mathrm{C}$ \\
\hline \multirow{2}{*}{ Fig. 5(c) } & (1) & 3.45 & 18.25 & 78.30 \\
\cline { 2 - 5 } & (2) & 86.74 & 11.18 & 2.08 \\
\hline
\end{tabular}

레이저파장을 사용한 결과 약 $1.00 ~ 1.33 \mathrm{~J} / \mathrm{cm}^{2}, 532 \mathrm{~nm}$ 의 경우는 약 $0.50 \sim 0.67 \mathrm{~J} / \mathrm{cm}^{2}$ 의 레이저에너지밀도 로 조사하였을 때 표면의 아크릴수지가 제거되었다. Paraloid B72 수지는 $1064 \mathrm{~nm}$ 의 경우 약 1.67 $2.00 \mathrm{~J} / \mathrm{cm}^{2}, 532 \mathrm{~nm}$ 의 경우 약 $0.67 \sim 1.00 \mathrm{~J} / \mathrm{cm}^{2}$ 의 레 이저에너지로 제거되었다. 그러나 레이저조사 후 표 면에 코팅된 아크릴수지만 제거되는 것이 아니라 청동 파티나 층까지도 함께 제거되어 소지금속이 노출되었다.

레이저 조사 후 청동유물편의 단면을 금속현미경 으로 관찰하였다. 그림 6은 $30 \mathrm{wt} \%$ Paraloid B72로 코팅한 청동유물편을 레이저파장 $532 \mathrm{~nm}, 0.50 \mathrm{~J} / \mathrm{cm}^{2}$ 로 조사하여 코팅면이 완전히 제거되지 않은 부분 (그림 $6 \mathrm{a}$ )과 $532 \mathrm{~nm}, 0.67 \mathrm{~J} / \mathrm{cm}^{2}$ 로 조사하여 소지금 속이 일부 노출된 부분(그림 $6 \mathrm{c}$ )의 단면을 관찰하 였다. $0.50 \mathrm{~J} / \mathrm{cm}^{2}$ 로 조사한 부분의 단면(그림 $6 \mathrm{~b}$ ) 관 찰결과 청동 소지금속 위의 파티나 층이 확인되며 코팅된 아크릴수지가 레이저조사에 의해 소지로부 터 약간 들떠 있는 것이 관찰된다. $0.67 \mathrm{~J} / \mathrm{cm}^{2}$ 의 경 우(그림 6d) 레이저 조사에 의해 아크릴수지가 완 전히 제거되었으나 파타나 층과 부식물 덩어리도 함께 제거되었다. 청동 파티나는 다공성이며 소지 금속에 단단하게 고착되어 있지 않아 아크릴수지가 파티나 층에 스며들고 경화되어 레이저에 의해 아 크릴수지와 함께 제거된 것으로 보인다.

\subsubsection{SEM-EDS 분석}

레이저파장 $532 \mathrm{~nm}$ 으로 $0.50 \mathrm{~J} / \mathrm{cm}^{2}$ 를 조사하여 표 면의 아크릴수지가 약간 들떠있는 상태를 SEM으

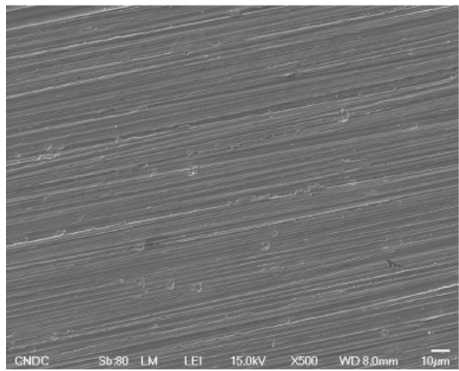

(a) $1064 \mathrm{~nm} 2.00 \mathrm{~J} / \mathrm{cm}^{2}$

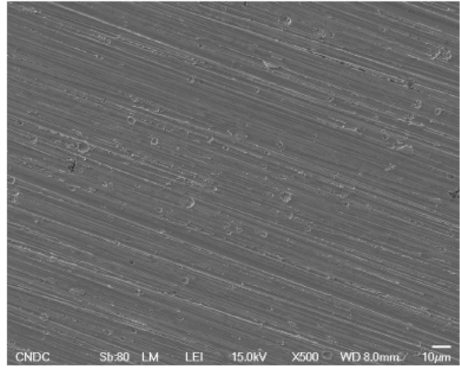

(b) $532 \mathrm{~nm} 1.00 \mathrm{~J} / \mathrm{cm}^{2}$

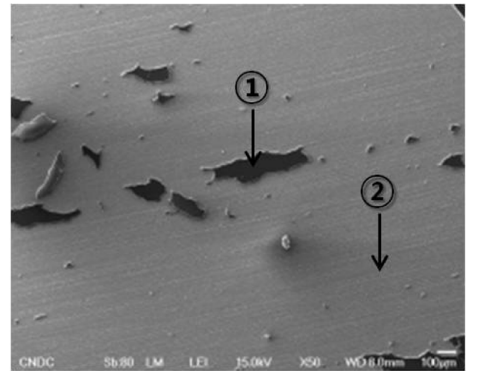

(c) $1064 \mathrm{~nm} 2.67 \mathrm{~J} / \mathrm{cm}^{2}$

Fig. 5. SEM images of copper coupon after laser irradiation : (a),(b) plain copper coupon, (c) 30 wt\% Paraloid NAD10. 


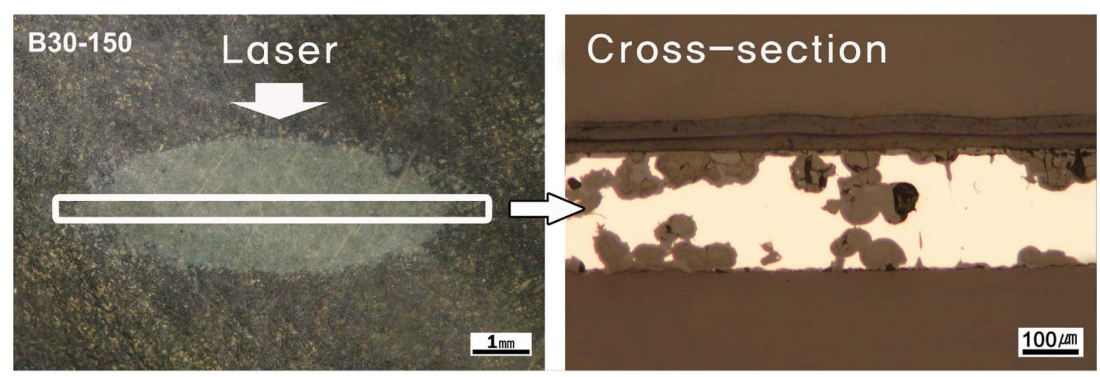

(a)

(b)

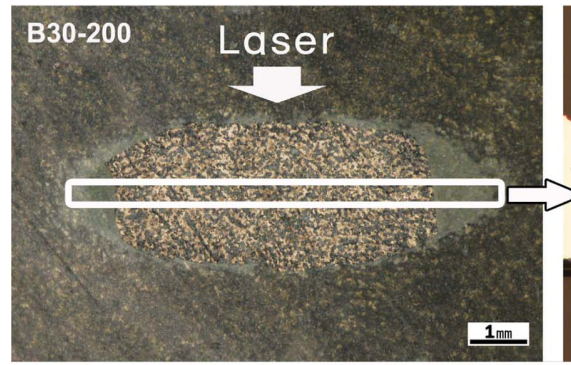

(c)

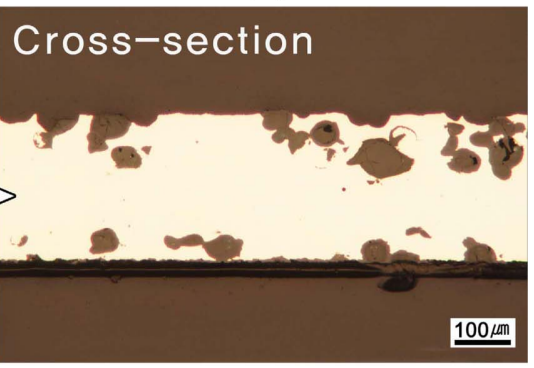

(d)

Fig. 6. Optical microscopy $(a, c)$ after laser irradiation and metallurgical microscopy $(b, d)$ of cross-section; (a),(b): $532 \mathrm{~nm}, 0.50 \mathrm{~J} / \mathrm{cm}^{2}$, (c),(d): $532 \mathrm{~nm}, 0.67 \mathrm{~J} / \mathrm{cm}^{2}$.

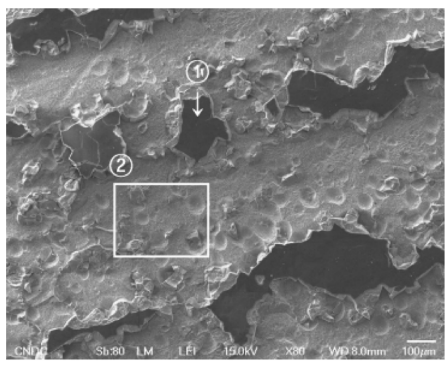

(a) $532 \mathrm{~nm} 0.50 \mathrm{~J} / \mathrm{cm}^{2}$

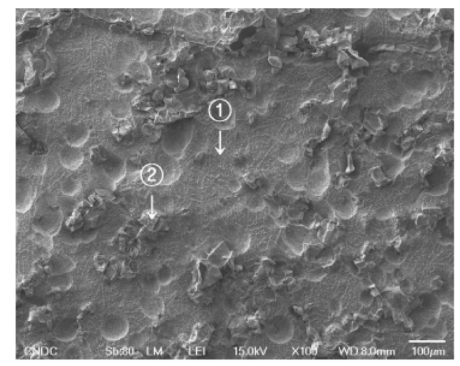

(b) $532 \mathrm{~nm} 1.17 \mathrm{~J} / \mathrm{cm}^{2}$

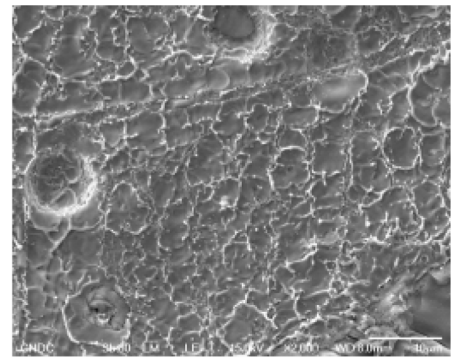

(c) Melting surface

Fig. 7. SEM images of bronze artefact samples after laser irradiation.

Table 6. EDS results of bronze artefact samples after laser irradiation (-: not detected)

\begin{tabular}{|l|c|c|c|c|c|c|c|c|c|}
\hline \multicolumn{2}{|c|}{ SEM-EDS } & \multicolumn{8}{c|}{ Chemical composition (wt\%) } \\
\cline { 3 - 11 } \multicolumn{2}{|c|}{} & $\mathrm{Cu}$ & $\mathrm{Sn}$ & $\mathrm{O}$ & $\mathrm{C}$ & $\mathrm{Si}$ & $\mathrm{Fe}$ & $\mathrm{Al}$ & $\mathrm{P}$ \\
\hline \multirow{2}{*}{ Fig. 7(a) } & (1) & 0.61 & 17.05 & 6.55 & 73.04 & 0.44 & 1.16 & 0.64 & 0.52 \\
\cline { 2 - 11 } & $(2)$ & 40.37 & 36.80 & 13.12 & 8.86 & 0.84 & - & - & - \\
\hline \multirow{2}{*}{ Fig. 7(b) } & (1) & 70.51 & 22.24 & - & 6.96 & - & - & - & - \\
\cline { 2 - 10 } & $(2)$ & 3.79 & 47.43 & 33.83 & 10.01 & 1.47 & 1.34 & 2.12 & - \\
\hline
\end{tabular}

로 관찰한 결과 일부 수지가 잔류하고 있었으며 소 지금속이 노출되었다(그림 7a). EDS 분석한 결과 잔류한 수지는 $73.04 \mathrm{wt} \% \mathrm{C}, 17.05 \mathrm{wt} \% \mathrm{Sn}, 6.55 \mathrm{wt} \%$ $\mathrm{O}$ 등이 검출되었으며 소지금속은 $40.37 \mathrm{wt} \% \mathrm{Cu}$, $36.80 \mathrm{wt} \% \mathrm{Sn}, 8.86 \mathrm{wt} \% \mathrm{C}$ 등이 검출되었다(표 6). $532 \mathrm{~nm} 0.50 \mathrm{~J} / \mathrm{cm}^{2}$ 보다 높은 레이저에너지밀도인 $1.17 \mathrm{~J} / \mathrm{cm}^{2}$ 로 조사하여 소지금속이 일부 노출된 표 면을 SEM-EDS로 분석한 결과 아크릴수지와 함께 청동 파티나가 제거되었으며 용융현상도 관찰되었 다(그림 $7 \mathrm{~b}, \mathrm{c}$ ). 또한 덩어리 형태의 결정물들이 관
찰되는데 $\mathrm{EDS}$ 분석 결과 $47.43 \mathrm{wt} \% \mathrm{Sn}, 33.83 \mathrm{wt} \%$ $\mathrm{O}$ 와 $\mathrm{Cu}, \mathrm{Si}$ 등이 소량 검출되어 산화주석화합물임 을 확인하였다(표 6). 이러한 결정물들은 레이저 조사에 의하여 덩어리로 떨어져 표면에 crater를 남 겼다.

\section{4. 결 론}

본 연구에서는 금속유물에 코팅된 아크릴수지를 $\mathrm{Nd}: Y A G$ 레이저기기를 이용하여 제거하고 그 활용 
가능성을 알아보았다. 레이저파장별 제거효과를 비 교하면 $532 \mathrm{~nm}$ 를 사용하였을 경우 $1064 \mathrm{~nm}$ 보다 낮은 레이저에너지에서 수지가 제거되었다. 또한 코 팅하지 않은 동판에 레이저를 조사한 결과 $1064 \mathrm{~nm}$ 는 $2.00 \mathrm{~J} / \mathrm{cm}^{2}, 532 \mathrm{~nm}$ 는 $1.00 \mathrm{~J} / \mathrm{cm}^{2}$ 미만의 레이저 에너지밀도를 사용하였을 경우 표면의 용융현상이 관찰되지 않았다. 따라서 아크릴수지에 대한 가장 효과적인 레이저클리닝 조건은 $532 \mathrm{~nm}$ 를 사용하여 $1.00 \mathrm{~J} / \mathrm{cm}^{2}$ 미만의 레이저에너지밀도로 1 2회 조사 하는 것으로 확인된다.

청동유물편에 아크릴수지를 코팅하고 레이저클리 닝을 실험한 결과 비교적 낮은 레이저에너지에서 제거되었으나 코팅된 아크릴수지만 제거되는 것이 아니라 청동 파티나도 함께 제거되었다. 청동 파티 나는 소지금속을 보호하고 청동유물의 고유 색상을 띠고 있어 보호해야 할 중요한 층이다. 따라서 청 동유물에 코팅된 아크릴수지를 제거하는데 $\mathrm{Nd}: \mathrm{YAG}$ 레이저의 한계성을 보이므로 다른 레이저기기나 다 른 파장대의 레이저 실험 연구가 필요할 것으로 본다.

\section{후 기}

본 연구는 문화재청 국립문화재연구소의 지원을 받아 문화재보존기술연구개발(R\&D) 사업의 일환으 로 이루어졌다.

\section{참고문헌}

1. J. M. Lee, Lasers and Cleaning Process, Hanrimwon, Seoul (2002) 53-62.

2. 국립문화재연구소, 경천사십층석탑 I. 해체에서 복 원까지, 국립문화재연구소, 대전 (2005) 94.

3. Roberto Pini, Salvatore Siano, Renzo Salimbeni, Marinella Pasquinucci, Marcello Miccio, J. Culu. Heritage, 1 (2000) 129.

4. Stefanie Scheerer, Meg Abraham, Odile Madden, J. Culu. Heritage, 4 (2003) 223.

5. M. P. Mateo, T. Ctvrtnickova, E. Fernandez, J. A. Ramos, A. Yez, G. Nicolas, Appl. Surf. Sci., 255 (2009) 5579.

6. M. Favaro, R. Mendichi, F. Ossola, U. Russo, S. Simon, P. Tomasin, P.A. Vigato, Polym Degrad Stab, 91 (2006) 3083.

7. Velson Horie, Materials for Conservation, Routledge, New York, 2nd cd, (2010) 153-165.

8. Rohm \& Hass Company, Acryloid Thermoplastic Solution Grade \& Solid Grade Acrylic Resins for Solvent-borne Industrial Finishing, Rohm \& Hass, (1992).

9. H. K. Cho, A Study on Characterization of Consolidants for Bronze Artifacts Conservation Using Surface Analysis, unpublished MA thesis, Kongju National University (2009) 44-48.

10. 윤능민, 용제포켓북, 대광서림 (2000). 